\title{
Effects of propagule settlement density and adult canopy on survival of recruits of Sargassum spp. (Sargassaceae: Phaeophyta)
}

\author{
Gary A. Kendrick* \\ Department of Botany, University of Western Australia, Nedlands, Western Australia 6009, Australia
}

\begin{abstract}
The effects of increased densities of settled propagules and the presence of adults on survival of recruits were investigated to determine whether patterns of propagule settlement would persist and be expressed as distribution of recruits for Sargassum spinuligerum, S. distichum and S. podacanthum in a subtidal mixed species bed at Rottnest Island, Western Australia. The effect of higher densities of settled propagules (recruit-recruit interactions) was studied using limestone settlement plates seeded with known densities of propagules. Density-dependent mortality occurred at settlement densities $<10^{5}$ propagules $\mathrm{m}^{-2}$ A large component of recruit mortality was density independent $157 \%$ of total mortality). Variability in recruit survival at any one settlement density was also great. Growth of recruits was negatively density dependent. Two distinct sizes of recruits were observed $(<10$ and $>10 \mathrm{~mm}$ in height). The effect of adult canopy (recruit-adult interactions) on recruit survival was studied using a clearing experiment where adult thalli were removed from $4 \mathrm{~m}^{2}$ areas. For the first 6 mo the presence of adults had little effect on recruit survival. After 6 mo, the presence of adults reduced recruit survival 3 -fold, and survival was highly variable either under canopies or in cleared areas. Distributions of dispersed propagules can persist as distributions of adults within beds of Sargassum spp. at Rottnest Island. More likely this would happen where patches within the bed are recolonized or where the bed is extended at its edges, because orders of magnitude differences in density of settled propagules would occur in these areas over distances of meters. Recruit survival at densities $<10^{5}$ ind. $\mathrm{m}^{-2}$ are equally influenced by density-dependent and density-independent processes. Presence of adult canopy reduces survival of recruits $>6$ mo old, but the amount that survival is reduced by canopy is not within the same range as differences in density of propagule settlement. The causes of high densityindependent mortality and its effect on patterns of propagule settlement need to be studied further
\end{abstract}

KEY WORDS: Sargassum sp. Recruitment - Intraspecific competition

\section{INTRODUCTION}

Dispersal distances of propagules of marine algae have usually been inferred from distributions of recruits (Anderson \& North 1966, Hruby \& Norton 1979, Deysher \& Norton 1982, Kennelly \& Larkum 1983, Hoffmann \& Ugarte 1985, Reed et al. 1988). The distribution of recruits, however, includes factors other than variable dispersal (Harper 1977, Connell 1985). Such factors are density-dependent mortality in recruits,

- Present address: CSIRO Marine Laboratories, PO Box 20 , North Beach, Western Australia 6020, Australia interactions with adult thalli, and mortality from grazing, disturbance, and physiological factors. Kendrick \& Walker (1991) observed that $98 \%$ of dispersed propagules of Sargassum spinuligerum Sonder settled within $1 \mathrm{~m}$ of their source. In a similar species, $S$. muticum (Yendo) Fensholt, the greatest densities of recruits occurred within 1 to $3 \mathrm{~m}$ of reproductive thalli (Deysher \& Norton 1982). Could these patterns of recruitment in Sargassum spp. truly reflect patterns of dispersal? To further investigate the relationship between dispersal of propagules and distribution of recruits, I studied the post-settlement survival of recruits. The experiments presented here address the effect of propagule settle- 
ment density on recruit mortality (recruit-recruit interactions\}, and the effect of a canopy of Sargassum spp on survival of recruits (adult-recruit interactions). Although there are many other processes that affect survival of young recruits, including graring, disturbance, and physiological requirements, these densityrelated recruit-recruit and adult-recruit interactions were chosen as they were most likely to respond in a non-random way to increases in the density of dispersed and settled propagules.

The effect of density-dependent interactions on the structure of populations has been studied extensively in terrestrial plants (Harper 1977) but not in marine algae. The few studies of density dependence in marine algae, mainly in kelps, have resulted in a range of conclusions including negative and positive densitydependent and density-independent growth, reproduction and survival. Black (1974) found negative density-dependent survival and growth in imtertidal populations of the kelp Egregia menziesii. In subtidal stands of Macrocystis pyrifera and Pterygophora californica, increased density inhibited the growth of juveniles (Dean et al. 1989, Reed 1990) and the amount of reproduction (Reed 1987). Sporophyte production was also found to decrease with increased gametophyte densities (Reed et al. 1991). The southern hemisphere kelp Ecklonia radiata and Sargassum sinclairii were reported to show positive density-dependent growth (Schiel \& Choat 1980). Increased density of thalli of Ascophyllum nodosum from mixed cohorts of individuals from different locations had no effect on their biomass (Cousens \& Hutchings 1983) Cousens \& Hutchings (1983) concluded that the variations in density-dependence of Ascophyllum, Chordaria, Sacchorhiza, Sargassum and Ecklonia were due to densities below those of the boundary condition defined by the $-3 / 2$ power, or self-thinning law (Harper 1977). Density-dependent processes can be important in modifying patterns of settlement, as has been shown for marine barnacles (Connell 1985, Sutherland 1990, Menge 1991). The influence of density-dependent interactions on the survival of Sargassum spp. recruits will be studied over a range of settlement densities.

For marine algae, a canopy of adults can also have an effect on the recruitment and growth of juveniles (Black 1974, Velimirov \& Griffiths 1979, Dayton et al. 1984, Reed \& Foster 1984, Santelices \& Ojeda 1984. Paula \& Eston 1987, Chapman 1989, de Eston \& Bussab 1.990). Many of these studies have concluded that adults restrict growth and survival of recruits. Canopy removal experiments in Sargassum spp. beds have resulted in very high densities of Sargassum spp. recruiting into areas without canopies (Paula \& Eston 1987). Surveys (Dean et al. 1989) and canopy thinning experiments (Dayton et al. 1984, Reed \& Foster 1984,
Santelices \& Ojeda 1984, Reed 1990) in Macrocystis spp populations have shown that adult-juvenile interactions are major factors in determining patterns of survival in kelp populations. The Sargassum species from Rottnest Island, Western Australia, are not expected to respond differently although this study hopes to document when and to what degree adult thalli influence recruit survival.

This paper addresses how settlement patterns resulting from dispersal can be modified during recruitment for Sargassum spinuligerum Sonder, S. distichum Sonder and $S$. podacanthum Sonder at Rottnest Island. The effect of post-settlement processes on patterns of dispersal were studied at both recruit-recruit and adultrecruit levels of interaction by investigating (1) the relationship between density of settled propagules and mortality of recruits of Sargassum and (2) the influence of existing Sargassum thalli, both as canopy and as juveniles, on settlement and survival of recruits.

\section{MATERIALS AND METHODS}

Two experiments were conducted at Nancy Cove, Rottnest Island, Western Australia (32 $02^{\prime} \mathrm{S}, 115^{\circ} 28^{\prime} \mathrm{E}$ ) within a $6 \mathrm{~m}$ deep Sargassum spp. bed. The experiments addressed the effect of density of settled propagules (recruit-recr uit experiment) and the effect of an existing canopy of Sargassum spp. (recruit-adult experiment) on recruit survival. The bed was extensive $\left(5000 \mathrm{~m}^{2}\right)$ and contained the species Sargassum decurrens (R. Brown ex Turner) C. Agardh, S. tristichum Greville \& C. Agardh ex Sonder, S. spinuligerum Sonder, S. distichum Sonder and $S$. podacanthum Sonder growing together (Kendrick 1993). Depth varied by less than $0.5 \mathrm{~m}$ within the bed and the substratum was a friable low relief limestone platform

Sargassum in this paper is used to denote the species $S$. spinuligerum, $S$. distichum and $S$. podacanthum. It was not possible to differentiate between these individual species as recruits. Adult thalli of $S$. spinuligerum, $S$. distichum and $S$. podacanthum are also morphologically similat and cannot be identified from each other without reproductive structures (Kendrick 1993). Propagules of S. spinuligerum were used exclusively to seed plates in the experiment studying recruit-recruit interactions because large numbers of reproductive thalli of $S$. spinuligerum were available at that time. S. spinuligerum also accounted for $63.5 \%$ of all reproductive thalli of $S$. spinuligerum, $S$. distichum and $S$. podacanthum recorded during the period of the experiment (Kendrick 1993). Recruits of all 3 species were measured in the recruit-adult experiment.

Settlement density and recruit mortality. The effect of settlement density on recruit mortality was assessed 
by seeding settlement plates with different densities of Sargassum propagules and placing them subtidally within a Sargassum bed for 6 mo (November 1990 to May 1991). Plates were then retrieved and the numbers of surviving recruits determined.

The settlement plates $(30 \times 27.5 \times 3 \mathrm{~cm})$ were made from cut limestone, to approximate the limestone substratum of the reefs at Rottnest. The settlement plates were conditioned prior to seeding by being immersed for 1 to $2 \mathrm{mo}$ in seawater filtered through $0.7 \mu \mathrm{m}$ Millipore GFC filters.

Densities used to seed settlement plates ranged from $2.5 \times 10^{4}$ to $8.0 \times 10^{6}$ propagules $\mathrm{m}^{-2}$. These densities were chosen as they represented the range in densities recorded in field studies of dispersing propagules (Kendrick \& Walker 1991, Kendrick 1992).

To obtain a sufficient amount of Sargassum propagules, reproductive thalli were immersed in filtered seawater $(0.7 \mu \mathrm{m}$ Millipore GFC), the propagules ripe for release being washed into the seawater. This mixture of propagules and seawater was then emptied onto a $10 \mathrm{~cm}$ diameter circular area in the middle of limestone plates where they were contained by a plexiglass template with a $10 \mathrm{~cm}$ diameter hole cut from its centre. The template was laid over the limestone settlement plate and stuck to it using non-toxic silicon grease. The plexiglass templates aided in the concentration and retention of propagules at the centre of each settlement plate and the circular shape of the template was found to give more even densities of settled propagules than square and rectangular shapes. The main reason for concentrating propagules within a small central area of the settlement plates was to reduce variations in growth of recruits associated with turbulence at the edges of plates.

Limestone plates were then placed into aquaria filled with seawater for approximately $24 \mathrm{~h}$. Twentyfour plates were seeded with propagules in this manner. Eight plates were not seeded with propagules but were soaked in filtered seawater. These plates were placed in the field with the seeded plates to determine the background levels of settlement and recruitment.

After $24 \mathrm{~h}$, seawater was poured over the surfaces of limestone plates to remove all unattached propagules. Densities of propagules attached to limestone plates were determined from 20 fields of view measured under a dissecting microscope. Settlement densities ranged from $10^{4}$ to $<10^{7}$ propagules $\mathrm{m}^{-2}$. Accurate counts of settled propagules were difficult under the highest densities. Therefore, the size of fields of view was changed as propagule densities increased (452 $\mathrm{mm}^{2}, 113 \mathrm{~mm}^{2}, 28 \mathrm{~mm}^{2}$ ) so approximately the same numbers of propagules were counted within each field of view.
Once propagules on the limestone blocks were counted, the blocks were wrapped in plastic bags filled with seawater and transported to the study area in aluminium frames to protect the seeded plates from damage. The effect of transport on the measured settlement densities was assessed on 24 and 25 November 1990. Four limestone plates that contained known densities of propagules were transported to the study location, taken into the subtidal zone, and then brought back to the lab where densities were recounted. Transport did not significantly affect settlement densities (2tailed paired $t$-test: 24 November 1990, $t=0.70, \mathrm{df}=3$, $\mathrm{p}>0.05 ; 25$ November 1990, $t=1.35, \mathrm{df}=3, \mathrm{p}>0.05$ ).

The limestone settlement plates were placed subtidally inside the Sargassum bed, in an $8 \times 4$ array (total blocks $=32$ ), within areas cleared of canopy. The limestone blocks were separated from each other by $1.2 \mathrm{~m}$. Their placement was randomized such that blocks with different settlement densities and 2 unseeded blocks were random within rows $(\mathrm{n}=8)$.

After 6 mo (May 1991) all limestone blocks were retrieved and the number of recruits growing in the central seeded area of each block was counted. Densities of settled propagules on the unseeded plates determined the naturally occurring recruit densities in the field and the mean density of recruits from unseeded plates was subtracted from recruit densities observed on seeded plates. There were 2 distinct sizes of recruits: individuals $<10 \mathrm{~mm}$ in length, with no more than 2 narrow lateral blades, and individuals $>10 \mathrm{~mm}$ in length which were more robust and had more than 2 fully developed lateral blades. Individuals were separated by size and the 2 sizes dried in an oven at $70^{\circ} \mathrm{C}$ for $48 \mathrm{~h}$, and weighed separately for each settlement plate. Recruits were washed in fresh water before drying and weighing.

The effect of settlement density on recruit survival was assessed as density of survivors, recruit mortality and \% mortality, plotted against settlement density. These represent the range of ways that this type of data has been presented in the literature and emphasize different aspects of the relationship between settlement density and subsequent recruit density. The density of survivors has been used to interpret the level of density dependence in marine organisms (Connell 1985. Davis 1987) but has several statistical problems (McGuinness \& Davis 1989). The density of survivors can be no more than density of settled propagules and the correlation coefficient measures variability in survival. Here, I assessed how variable survival was by plotting the number of survivors against settlement density. Recruit mortality was determined by subtracting the densities of surviving recruits $\left(\mathrm{m}^{-2}\right)$ recorded in May 1991 from the densities $\left(\mathrm{m}^{-2}\right)$ of propagules settled onto the limestone plates in November 1990. The 
density relationship between recruit mortality and settlement density is determined from a linear regression with a slope between 0 and $45^{\circ}$ (McGuinness \& Davis 1989). Percent (recruit) mortality is recruit mortality represented as a percentage of settlement density. Negative and positive slopes from the linear regression of percent mortality against settlement density represent negative and positive density dependence and a slope of zero represents density independence (Holm 1990). The $y$-intercept represents the level of density-independent mortality. Linear regressions were determined for recruit mortality and \% mortality against settlement density. A Spearman rank order correlation coefficient was determined for density of survivors plotted against settlement density. Before linear regressions, all data were tested for normality using the studentized range test (Madansky 1988). Dependent variables were natural log transformed to conform to assumptions of normality, whereas independent variables were natural log transformed because the relationship between dependent and independent variables was non-linear. Graphs are presented in $\log _{10}$ transformations for ease of interpretation.

To determine the relationship between recruit biomass and density at the end of the experiment (month of May 1991), average biomass of individuals was regressed against the density of recruits. Regression analyses were also performed on the 2 size classes of recruits, separately. Transformations (natural log) were applied to data where appropriate, as described above.

Effect of canopy on recruit survival. The effect of a canopy of adults of Sargassum on the survival of recruits was investigated by a clearing experiment within the subtidal Sargassum bed at Nancy Cove, Rottnest Island. A block design was used within a $60 \mathrm{~m}^{2}$ area of the bed to facilitate sampling the same area over time in variable sea conditions and underwater visibility. The $60 \mathrm{~m}^{2}$ area was divided. into 15 $(2 \times 2 \mathrm{~m}$ ) blocks during September 1989 (Fig. 1). Treatments were randomly assigned to these 15 blocks, with 5 blocks per treatment. The treatments were: (1) removal of all algae to assess the effect of a canopy of adult Sargassum on the survival of recruits; (2) removal of smaller understorey algae but the Sargassum canopy was left intact - this was to control for the effects of understorey algae, rather than canopy, on recruit survival; and (3) control (unmanipulated) - this was to control for the effects of clearing on recruit survival.

Treatments were initially cleared of algae in September 1989 using knives to clear away the bulk of thalli and holdfasts, and wire brushes to remove any large fragments remaining on the limestone reef. It was very difficult to remove holdfasts totally and small thalli
( $<3 \mathrm{~cm}$ in height) regenerated from fragments of holdfasts between September and October 1989. Treatments were cleared a second time in October 1989 before the experiment was started. Still, thalli quickly regenerated from fragments of holdfast left on the reef during the experiment and confounded the treatment effect; the effect of regenerated thalli on recruits was not known. The densities of thalli regenerating from fragments of holdfasts were recorded separately from recruitment from propagules. Regenerated thalli grew from a black diffuse crust on the substratum and were more robust and had thicker stipes with narrower lateral blades than recruits. Recruits had thin stipes, broad, leaf-like lateral blades and a distinct olivecoloured conical holdfast.

Density of recruits and thalli regenerating from fragments of holdfasts was determined at monthly intervals between November 1989 and April 1990, then bimonthly, for logistical reasons, until October 1990. Densities were determined from 10 randomly located $20 \times 20 \mathrm{~cm}\left(0.04 \mathrm{~m}^{2}\right)$ quadrats placed within the central $1 \mathrm{~m}^{2}$ of each $2 \times 2 \mathrm{~m}$ block (Fig. 1), a total of 50 quadrats were sampled for each treatment at each time. Small quadrats $\left(0.04 \mathrm{~m}^{2}\right)$ were used because recruit densities were high and there were time constraints on collecting these data using SCUBA. Sampling the central $1 \mathrm{~m}^{2}$ of each block left a $0.5 \mathrm{~m}$ buffer against edge ef-

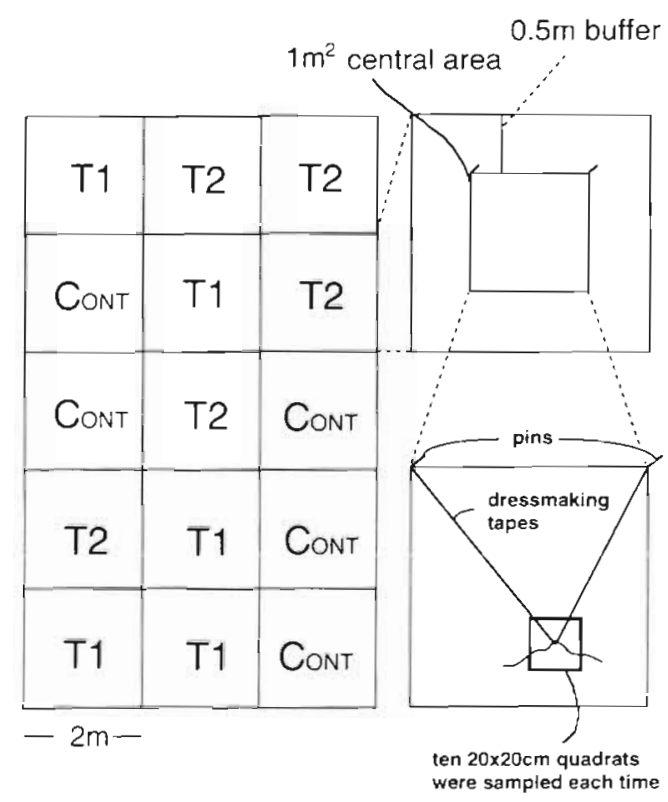

Fig. 1. Layout and sampling method of clearing experiment, October 1989-1990. A $3 \times 5$ array of $4 \mathrm{~m}^{2}$ blocks was set up and treatments randomly assigned to them. Treatments - T1 removal of all algae; $\mathrm{T} 2$ : removal of understorey algae but canopy left intact; Cont: unmanipulated control. A $1 \mathrm{~m}^{2}$ area was sampled within the blocks and from that area, ten $20 x$

$20 \mathrm{~cm}$ quadrats were taken each sampling period 
fects. The size of the buffer was determined by the average height of adult thalli $(0.40 \mathrm{~m})$ in the study area.

Usually, the central $1 \mathrm{~m}^{2}$ of the experimental blocks would have been subsampled by overlaying a fixed grid of twenty-five $20 \times 20 \mathrm{~cm}\left(0.04 \mathrm{~m}^{2}\right)$ quadrats and randomly subsampling the grid of quadrats over time. Sampling 10 quadrats from such a grid would have meant $40 \%$ of possible combinations were sampled every time and may have resulted in temporal pseudoreplication over a period of 6 mo to a year. Using a fixed grid was also found to damage young recruits when it was laid over them. The method used here involved the locating of the centre of each random $20 \times 20 \mathrm{~cm}$ quadrat using flexible dress-making tapes. These tapes were attached to pins located $1 \mathrm{~m}$ apart, that defined the upper corners of the central $1 \mathrm{~m}^{2}$ within blocks. Pairs of random numbers representing distances along the tapes to the nearest $2 \mathrm{~cm}$ were used to locate the position of the centre of quadrats. The method increased the number of possible placements of $20 \times 20 \mathrm{~cm}$ quadrats within the central $1 \mathrm{~m}^{2}$ portion of blocks at any one time to 1600 , although these placements were overlapping, thus reduced the likelihood of temporal pseudoreplication. The method was found to cause the least amount of damage to recruits.

The clearing experiment was initially designed to be analysed as a partially hierarchical ANOVA, using time, treatment and block, nested within treatment, as the factors, but it became difficult to continue with this design. The experiment was designed to run over $6 \mathrm{mo}$, but at the end of that period it was extended to 12 mo. This resulted in the possibility of temporal pseudoreplication occurring between sampling dates. Instead of continuing the analysis as planned, each sampling time was analysed independently with a 2 way nested ANOVA, with recruit density as the dependent variable. Mean square variance components are also presented. Recruit density data were $\sqrt{x+1}$ transformed to meet assumptions of normality (Studentized Range Statistic; Madansky 1988) and heterogeneity of variances (Cochran's test; Eisenhart \& Solomon 1947). Trends over time were presented graphically.

\section{RESULTS}

\section{Settlement density and recruit mortality}

$$
\text { Mortality }
$$

There was an almost $1: 1$ relationship between density of settled propagules and mortality of recruits across the range of settlement densities studied $\left(10^{4}\right.$ to $10^{7}$ propagules $\mathrm{m}^{-2}$ ) (Fig. $2 \mathrm{~A}$; mortality $=\mathrm{e}^{-0.6576}$ (settle-
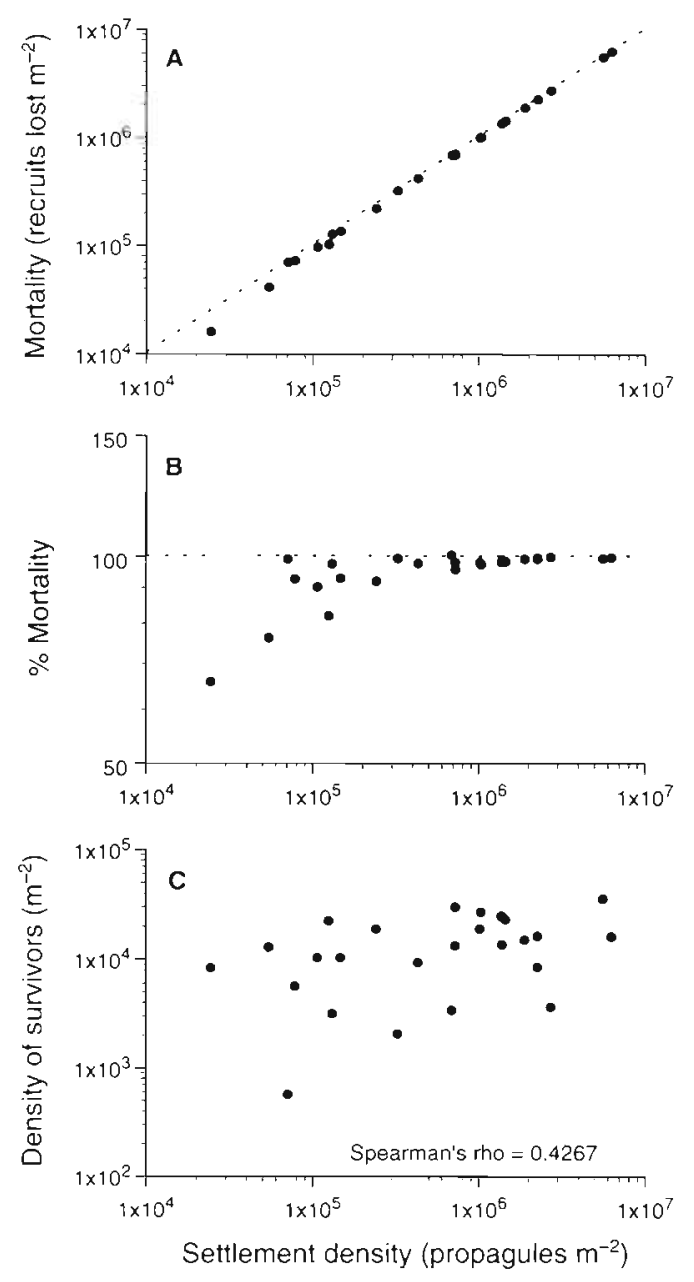

Fig. 2. Sargassum spp. Relationship between settlement density and (A) mortality of recruits, (B) \% mortality of recruits, and $(C)$ density of survivors. Axes were $\log _{10}$ transformed

ment density) ${ }^{10456}, \mathrm{r}^{2}=0.998, \mathrm{p}=0.0001, \mathrm{n}=24$ ) which suggests density-independent mortality was predominant. The exception to this trend was at densities less than $10^{5}$ propagules $\mathrm{m}^{-2}$, with more recruits surviving at lower densities.

When the same data are presented as \% mortality, a smaller percentage of recruits died at settlement densities $\leq 10^{5}$ propagules $\mathrm{m}^{-2}$ (Fig. $2 \mathrm{~B}$ ), implying densitydependent mortality occurred, although the rate was

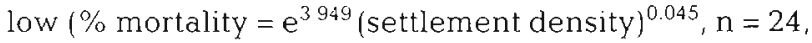
$r^{2}=0.486, p=0.0001$ ). If the linear regression is extrapolated to a density of settled propagules near zero, \% mortality of recruits nears $52 \%$. This intercept represents the levels of recruit mortality independent of density of settled propagules.

The spread of densities of survivors at any settlement density was large (Fig. 2C) suggesting that factors other than settlement density are affecting survival (Spearman rank correlation coefficient $\rho=$ $0.4267, n=24$ ). 
Naturally occurring levels of recruitment were measured on the unseeded limestone plates. Mean densities of recruits were 3729 recruits $\mathrm{m}^{-2}$ (SE 750 , $n=7$ ) and ranged from 2100 to 7800 recruits $\mathrm{m}^{-2}$. The density of recruits on unseeded plates was approximately an order of magnitude lower than seeded densities.

\section{Biomass}

Density-dependent growth occurred. The average biomass of individual recruits decreased 8 -fold as density of recruits on the experimental plates increased from less than 100 individuals (Fig. 3). This trend was significant $\left(r^{2}=0.708, n=31, p=0.0001\right)$. There were 2 distinct sizes of recruits. Average biomass of individual recruits $<10$ and $>10 \mathrm{~mm}$ in size showed a negative trend with increasing recruit density (Fig. 4) although the slope and coefficient of determination were less than for all sizes of recruits combined (Fig. 3). There was an increase in the numbers of recruits $<10 \mathrm{~mm}$ contributing to overall recruit density as total density increased (Fig. 5). There was an almost 1:1 relationship (slope $=0.93$ ) between the density of recruits $<10 \mathrm{~mm}$ and overall recruit density. An equal number of larger recruits (>10 mm) developed at all settlement
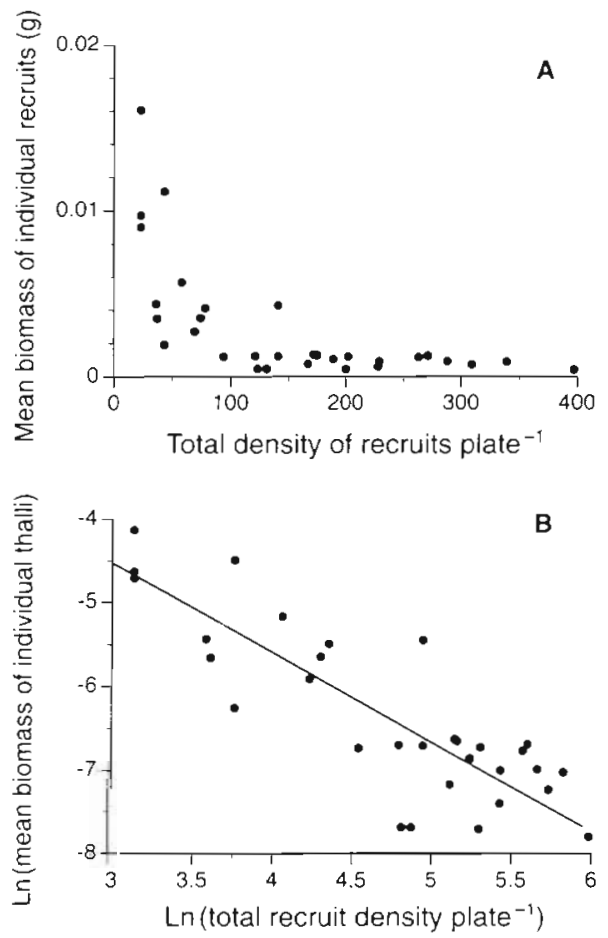

Fig. 3. Sargassum spp. Variation in mean biomass of recruits with increase in density of recruits on settlement plates, May 1990: (A) untransformed and (B) natural log transformation of both axes. Regression of the natural log transformed data: $\mathrm{y}=\mathrm{e}^{-1.576} \mathrm{x}^{-1.012}, \mathrm{n}=31, \mathrm{r}^{2}=0.708, \mathrm{p}=0.0001$

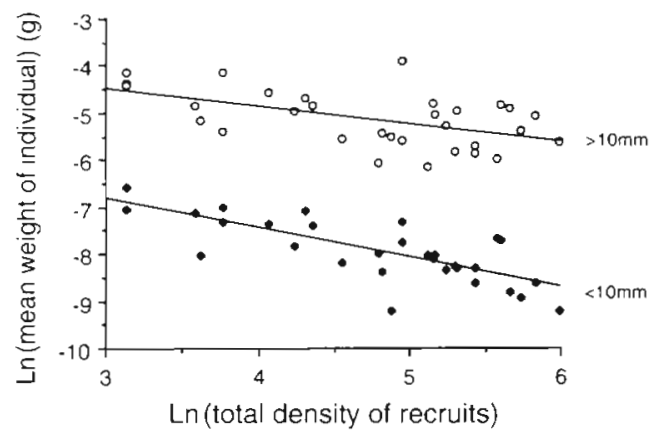

Fig. 4. Sargassum spp. Variation in mean biomass of recruits with increase in density of recruits on settlement plates, May 1990 for recruits $>10$ and $<10 \mathrm{~mm}$ in length. Regression equation for recruits $>10 \mathrm{~mm}: y=e^{-3.360} x^{-0.375}, \mathrm{n}=31, \mathrm{r}^{2}=0.288$, $\mathrm{p}=0.002 ;$ and for recruits $<10 \mathrm{~mm}: y=\mathrm{e}^{-4.928} \mathrm{x}^{-0.633}, \mathrm{n}=30$ $r^{2}=0.5796, p=0.0001$

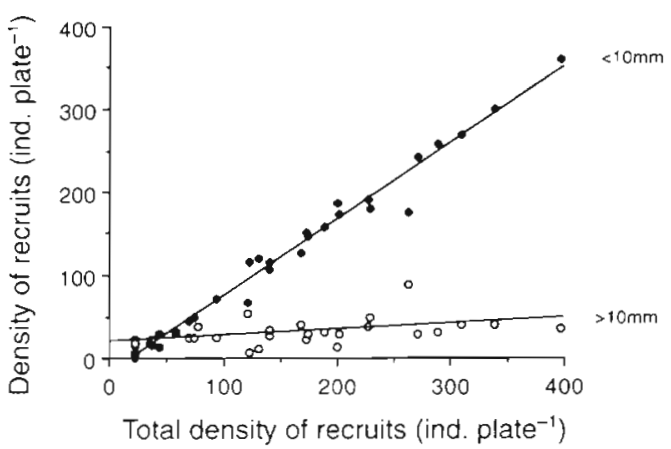

Fig. 5. Sargassum spp. Relationship between density of recruits $<10$ and $>10 \mathrm{~mm}$, and total density of recruits, May 1990. Regression for $<10 \mathrm{~mm}: y=0.93(x)-19.414, \mathrm{n}=31$, $r^{2}=0.980, p=0.0001 ;$ and $>10 \mathrm{~mm}: y=19.414+0.07(x)$. $\mathrm{n}=31, \mathrm{r}^{2}=0.222, \mathrm{p}=0.0075$

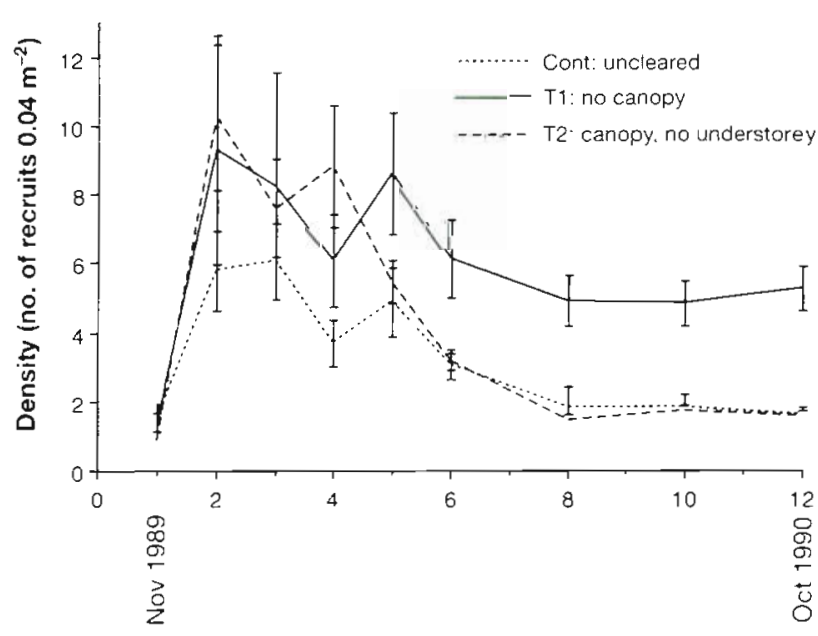

Fig. 6. Sargassum spp. Change in mean density of recruits $( \pm S E, n=5)$ in treatments and control plots with time after clearing (October 1989). Treatments - T1: no canopy (removal of all algae); T2: removal of understorey algae but canopy of Sargassum left intact; Cont: an unmanipulated control 
densities. Densities of recruits $>10 \mathrm{~mm}$ were also more variable between plates with similar total recruit densities, as shown by a coefficient of determination $\left(r^{2}\right)$ of 0.222 .

\section{Effect of canopy on recruit survival}

The number of recruits observed in the clearing experiment was an order of magnitude lower than that observed during the settlement plate experiment. Highest densities of recruits were recorded in all treatments 2 mo after clearing (6 to 10 recruits $0.04 \mathrm{~m}^{-2}$, or 150 to 250 recruits $\mathrm{m}^{-2}$ ) (December 1989) (Fig. 6).

There was no significant difference (Table 1, p > $0.05)$ between treatments and control for the first 5 mo after clearing. This unexpected similarity between treatments and control mirrored the loss of the Sargassum canopy in the study area after they reproduced (December 1989). There was no canopy in the Sargassum bed from January to April 1990. Also, density counts varied greatly during this time (Fig 6).
From the sixth month (April 1990) to the end of the experiment (October 1990), the treatment where canopy was removed was significantly higher in recruit density than the understorey clearing treatment and the control (Table 1, Fig 6). Both understorey clearing and control had similar densities. In April 1990, regrowth of annual thalli from perennial bases was observed in both these treatments. Standard errors in density counts were much reduced in the 6 to 12 mo period.

Recruitment was variable between blocks of the same treatment, separated by distances of less than $10 \mathrm{~m}$, and between replicate quadrats within blocks. Block effects within treatments were significant at all times except the first month sampled (November 1989) (Table 1). Also, mean square variance components (as \% $s^{2}$ of MS) were largest between replicate quadrats within blocks for all months except the last month sampled (October 1990) (Table 2). There was an increase in the mean square variance component accounted for by treatments over the experiment which suggests that canopy significantly affects survival of recruits greater than 6 mo of age. Early

Table 1 Summary of 2 -factor nested ANOVAs with treatment $(n=3)$ as a fixed factor and block $(n=5)$ nested within treatment for individual months of sampling. The dependent variable, density of recruits, was transformed ( $\sqrt{\text { density }+1})$ to meet homogeneity of variance assumptions. An a posteriori Tukey test was used for comparisons between treatments from significant ANOVAs. Treatments - T1 complete removal of all algae; T2: canopy remains, all understorey removed; Cont: unmanipulated

\begin{tabular}{|c|c|c|c|c|c|c|c|}
\hline Date & Time (mo) & Source & $\mathrm{df}$ & Treatment MS & F-statistic & $\mathrm{p}$ & Tukey summary \\
\hline Nov 1989 & 1 & $\begin{array}{l}\text { Treatment } \\
\text { Block (Treat) } \\
\text { Residual }\end{array}$ & $\begin{array}{r}2 \\
12 \\
135\end{array}$ & $\begin{array}{l}0.526 \\
0.409 \\
0.343\end{array}$ & $\begin{array}{l}1.285 \\
1.192\end{array}$ & $\begin{array}{l}0.3120 \\
0.2952\end{array}$ & \\
\hline Dec 1989 & 2 & $\begin{array}{l}\text { Treatment } \\
\text { Block (Treat) } \\
\text { Residual }\end{array}$ & $\begin{array}{r}2 \\
12 \\
135\end{array}$ & $\begin{array}{l}7.792 \\
7.011 \\
2.462\end{array}$ & $\begin{array}{l}1.111 \\
2.840\end{array}$ & $\begin{array}{l}0.3608 \\
0.0017\end{array}$ & \\
\hline Jan 1989 & 3 & $\begin{array}{l}\text { Treatment } \\
\text { Block (Treat) } \\
\text { Residual }\end{array}$ & $\begin{array}{r}2 \\
12 \\
135\end{array}$ & $\begin{array}{l}2.322 \\
5.092 \\
1.708\end{array}$ & $\begin{array}{l}0.456 \\
2.982\end{array}$ & $\begin{array}{l}0.6444 \\
0.0010\end{array}$ & \\
\hline Feb 1990 & 4 & $\begin{array}{l}\text { Treatment } \\
\text { Block (Treat) } \\
\text { Residual }\end{array}$ & $\begin{array}{r}2 \\
12 \\
135\end{array}$ & $\begin{array}{r}10.396 \\
3.116 \\
1.234\end{array}$ & $\begin{array}{l}3.337 \\
2.824\end{array}$ & $\begin{array}{l}0.0704 \\
0.0050\end{array}$ & \\
\hline Mar 1990 & 5 & $\begin{array}{l}\text { Treatment } \\
\text { Block (Treat) } \\
\text { Residual }\end{array}$ & $\begin{array}{r}2 \\
12 \\
135\end{array}$ & $\begin{array}{l}7.666 \\
2.869 \\
1.033\end{array}$ & $\begin{array}{l}2.672 \\
2.776\end{array}$ & $\begin{array}{l}0.1097 \\
0.0021\end{array}$ & \\
\hline Apr 1990 & 6 & $\begin{array}{l}\text { Treatment } \\
\text { Block (Treat) } \\
\text { Residual }\end{array}$ & $\begin{array}{r}2 \\
12 \\
135\end{array}$ & $\begin{array}{l}8.121 \\
1.436 \\
0.536\end{array}$ & $\begin{array}{l}5.657 \\
2.678\end{array}$ & $\begin{array}{l}0.0186 \\
0.0029\end{array}$ & $\mathrm{~T} 1 \neq \mathrm{T} 2=\mathrm{Con} \mathrm{t}$ \\
\hline Jun 1990 & 8 & $\begin{array}{l}\text { Treatment } \\
\text { Block (Treat) } \\
\text { Residual }\end{array}$ & $\begin{array}{r}2 \\
12 \\
135\end{array}$ & $\begin{array}{r}12.411 \\
0.993 \\
0.319\end{array}$ & $\begin{array}{r}12.501 \\
3.108\end{array}$ & $\begin{array}{l}0.0012 \\
0.0004\end{array}$ & $\mathrm{~T} 1 \neq \mathrm{T} 2=\mathrm{Cont}$ \\
\hline Aug 1990 & 10 & $\begin{array}{l}\text { Treatment } \\
\text { Block (Treat) } \\
\text { Residual }\end{array}$ & $\begin{array}{r}2 \\
12 \\
135\end{array}$ & $\begin{array}{r}11.496 \\
0.640 \\
0.269\end{array}$ & $\begin{array}{r}17.975 \\
2.382\end{array}$ & $\begin{array}{l}0.0002 \\
0.0081\end{array}$ & $\mathrm{~T} 1 \neq \mathrm{T} 2=\mathrm{Cont}$ \\
\hline Oct 1990 & 12 & $\begin{array}{l}\text { Treatment } \\
\text { Block (Treat) } \\
\text { Residual }\end{array}$ & $\begin{array}{r}2 \\
12 \\
135\end{array}$ & $\begin{array}{r}16.717 \\
0.535 \\
0.241\end{array}$ & $\begin{array}{r}31.248 \\
2.218\end{array}$ & $\begin{array}{l}0.0001 \\
0.0140\end{array}$ & $\mathrm{~T} 1 \neq \mathrm{T} 2=\mathrm{Cont}$ \\
\hline
\end{tabular}


Table 2. Treatment block and residual MS variance components (as $\% \mathrm{~s}^{2}$ of $\mathrm{MS}$ ) from 2 -factor nested ANOVAs with treatment as a fixed factor and block nested within treatment for each month of sampling

\begin{tabular}{|c|c|c|c|c|}
\hline Date & Time (mo) & Source & $\mathrm{n}$ & $\% \mathrm{~s}^{2}$ of $\mathrm{MS}$ \\
\hline Nov 1989 & 1 & $\begin{array}{l}\text { Treatment } \\
\text { Block(Treat) } \\
\text { Residual }\end{array}$ & $\begin{array}{c}3 \\
5 \\
10\end{array}$ & $\begin{array}{r}0.665 \\
1.875 \\
97.460\end{array}$ \\
\hline Dec 1989 & 2 & $\begin{array}{l}\text { Treatment } \\
\text { Block(Treat) } \\
\text { Residual }\end{array}$ & $\begin{array}{c}3 \\
5 \\
10\end{array}$ & $\begin{array}{r}0.533 \\
15.512 \\
83.955\end{array}$ \\
\hline Jan 1990 & 3 & $\begin{array}{l}\text { Treatment } \\
\text { Block(Treat) } \\
\text { Residual }\end{array}$ & $\begin{array}{c}3 \\
5 \\
10\end{array}$ & $\begin{array}{r}0.000 \\
16.536 \\
83.464\end{array}$ \\
\hline Feb 1990 & 4 & $\begin{array}{l}\text { Treatment } \\
\text { Block(Treat) } \\
\text { Residual }\end{array}$ & $\begin{array}{c}3 \\
5 \\
10\end{array}$ & $\begin{array}{r}9.287 \\
12.004 \\
78.709\end{array}$ \\
\hline Mar 1990 & 5 & $\begin{array}{l}\text { Treatment } \\
\text { Block(Treat) } \\
\text { Residual }\end{array}$ & $\begin{array}{c}3 \\
5 \\
10\end{array}$ & $\begin{array}{r}7.309 \\
13.988 \\
78.702\end{array}$ \\
\hline Apr 1990 & 6 & $\begin{array}{l}\text { Treatment } \\
\text { Block(Treat) } \\
\text { Residual }\end{array}$ & $\begin{array}{c}3 \\
5 \\
10\end{array}$ & $\begin{array}{l}17.599 \\
11.847 \\
70.554\end{array}$ \\
\hline Jun 1990 & 8 & $\begin{array}{l}\text { Treatment } \\
\text { Block(Treat) } \\
\text { Residual }\end{array}$ & $\begin{array}{c}3 \\
5 \\
10\end{array}$ & $\begin{array}{l}37.146 \\
10.964 \\
51.890\end{array}$ \\
\hline Aug 1.990 & 10 & $\begin{array}{l}\text { Treatment } \\
\text { Block(Treat) } \\
\text { Residual }\end{array}$ & $\begin{array}{c}3 \\
5 \\
10\end{array}$ & $\begin{array}{r}41.497 \\
7.091 \\
51.412\end{array}$ \\
\hline Oct 1990 & 12 & $\begin{array}{l}\text { Treatment } \\
\text { Block(Treat) } \\
\text { Residual }\end{array}$ & $\begin{array}{c}3 \\
5 \\
10\end{array}$ & $\begin{array}{r}54.481 \\
4.949 \\
40.570\end{array}$ \\
\hline
\end{tabular}

recruitment seems unaffected by canopy or understorey.

\section{Thallus regeneration}

Regeneration of thalli from fragments of holdfasts left on the substratum occurred throughout the experiment. The densities of thalli produced from vegetative regeneration increased over the first few months of the experiment for all treatments. Highest densities were recorded in January 1990, followed by a decline to low densities in August to November 1990 (Fig 7). The cleared treatment exhibited highest densities (5 thalli $0.04 \mathrm{~m}^{-2}$, January 1990). Clearing had a positive impact on the production of thalli through vegetative regeneration. The control and the treatment where understorey algae were cleared, but the Sargassum canopy left intact, had similar densities of regenerated thalli throughout the experiment. The densities of regenerated thalli in these treatments were approximately $1 / 2$ of the densities in the canopy-cleared treatment during the first 5 mo of the experiment.

\section{DISCUSSION}

The survival and growth of Sargassum recruits are influenced by both density-dependent and densityindependent processes. Density-dependent interactions occur between recruits and between recruits and adults. These interactions will influence the persistence of patterns of settled propagules. Density-dependent recruit mortality occurs at densities of settled propagules less than $10^{5}$ propagules $\mathrm{m}^{-2}$. Densityindependent mortality is high. Causes and effect of high density-independent mortality on patterns of propagule settlement need further study. Presence of adult canopy reduces recruit survival, but only in recruits older than 6 mo of age

Density-dependent mortality occurs in recruit populations, but at a low rate. Populations showing densitydependent mortality are believed to be regulated by post-settlement processes, as dependence of population structure on larval settlement can be removed (Connell 1985, Victor 1986). However, recruitment can reflect settlement over a range of density-dependent and density-independent mortalities, especially when settlement densities are low and uneven in space (Holm 1990, Hughes 1990, Sutherland 1990, Menge 1991). Propagule settlement in Sargassum can be uneven in space. There is an exponential decline in settling propagules within $2 \mathrm{~m}$ distances of parents (Kendrick \& Walker 1991).

Factors other than density-regulated processes are also important in determining survival of Sargassum recruits. Density-independent mortality accounted for over half of total recruit mortality. Factors producing high density-independent mortality could include grazing, and light and nutrient requirements. Grazing by sea urchins was shown to reduce recruitment of microscopic stages of Macrocystis pyrifera in southern California, USA (Dean et al. 1988). Light and nutrient requirements for recruits may also affect settlement and survival in a density-independent fashion (Hoffman et al. 1984, Amsler \& Neushul 1991). Successful gametogenesis and growth of sporophytes in kelps were found to have specific nutrient and light requirements (Deysher \& Dean 1986). Wave action (Vadas et al. 1990) and sediment movement (Devinny \& Volse 1978) may also affect kelp recruit survival. Similar requirements may exist for Sargassum recruits.

Density-dependent growth was occurring even in 6 mo old cohorts of Sargassum recruits. The Sargassum species studied here showed a negative trend in biomass with increased densities of 6 mo old recruits and there was a skewing of frequencies of size classes towards smaller individuals. These results are similar to observations made on kelps in northwestern North America (Black 1974, Reed 1987, 1990, Dean et al. 
1989, Reed et al. 1991) although are different to the observations of Schiel \& Choat (1980) from New Zealand. Schiel \& Choat (1980) found thalli of Ecklonia radiata and Sargassum sinclairii increased in biomass as stand density increased. The present experiment was stopped after 6 mo and so observed densitydependent growth of recruits should not be extrapolated to either recruits less than 6 mo old, or adult stands of Sargassum.

Density-dependent growth was recorded but its impact on the survival of recruits in marine algae may be modified by arrested development in recruits. The 2 distinct size classes suggest arrested growth in the small size class, but whether this results in death of all individuals from the smaller size class is unknown. Arrested development in juveniles has been described from populations of Sargassum sinclairii (Schiel 1985) and Fucus distichus (Ang 1991). Skewing of size distributions towards more smaller sized thalli as density of populations increase has also been described for the kelps Pterygophora californica (Reed 1990) and Macrocystis pyrifera (Dean et al. 1989). How arrested juvenile development can affect the persistence of settlement patterns and whether it occurs with enough frequency to uncouple recruitment from dispersal need further study

Adult thalli affected the recruitment of juveniles over a 12 mo period. In cleared areas, 3 times more recruits survived their first year of life than in uncleared controls and in treatments that remove only the understorey. Similarly, recruitment of Sargassum stenophyllum (Paula \& Eston 1987), juvenile abundance of Fucus spiralis (Chapman 1989), and biomass of juveniles of Macrocystis pyrifera (Santelices \& Ojeda 1984) increased in areas cleared of canopy. Such a pattern of survival would alter patterns of dispersal so that the distribution of adults may reflect the disturbance history of the stand of Sargassum.

For Sargassum species at Rottnest Island, the seasonal pattern of growth, reproduction and senescence of annual thalli both enhances and inhibits rates of recruitment. Recruit densities were not affected by the presence of an adult canopy during October, November and December and there was effectively no canopy during the next 3 mo of recruitment (January, February, March). Therefore, Sargassum canopy does not form a barrier to settling propagules as suggested for other Sargassum species (Ang 1985, de Eston \& Bussab 1990) and other marine benthic algae (Dayton et al. 1984, Schiel \& Foster 1986). Annual thalli regrow from perennial bases in April and the growth of annuals reduces survival of recruits. Growth rates of the annuals are much greater than recruits and they are more firmly attached to the substratum. Thus, recruit densities after 6 mo were much less in areas where the canopy was not cleared than where it was. It is not known what causes the negative effects adult thalli have on recruits. Possible processes responsible for reduced survival under adult canopies include reduction of light caused by shading (Dayton et al. 1984, Reed \& Foster 1984, Santelices \& Ojeda 1984, Kennelly 1989) and physical scouring (Black 1974, Velimirov \& Griffiths 1979). The differences in size between recently settled and $>6$ mo old recruits probably account for their different responses to the presence of canopy. Over the last 6 mo of the experiment, the treatment where the understorey was removed had similar numbers of recruits to the unmanipulated control, suggesting that it was the presence of a canopy of older thalli that directly influenced the survival of recruits.

Spatial patterns of recruitment were affected by scales of processes equal to and less than the $4 \mathrm{~m}^{2}$ blocks of the clearing experiment. A major source of variation in the ANOVAs was the differences between blocks within treatments, and between $0.04 \mathrm{~m}^{2}$ quadrats sampled randomly within blocks. This implies that patchiness in dispersal of propagules (Kendrick \& Walker 1991), and/or recruit survival were at these scales. Similar variable recruitment patterns were also reported in areas cleared of Sargassum stenophyllum in Brazil (de Eston \& Bussab 1990). For the first 5 mo of the experiment, the uncleared control had similar, variable recruit densities to the canopy and understorey cleared treatments. This suggests that influences other than intraspecific competition are important in determin-

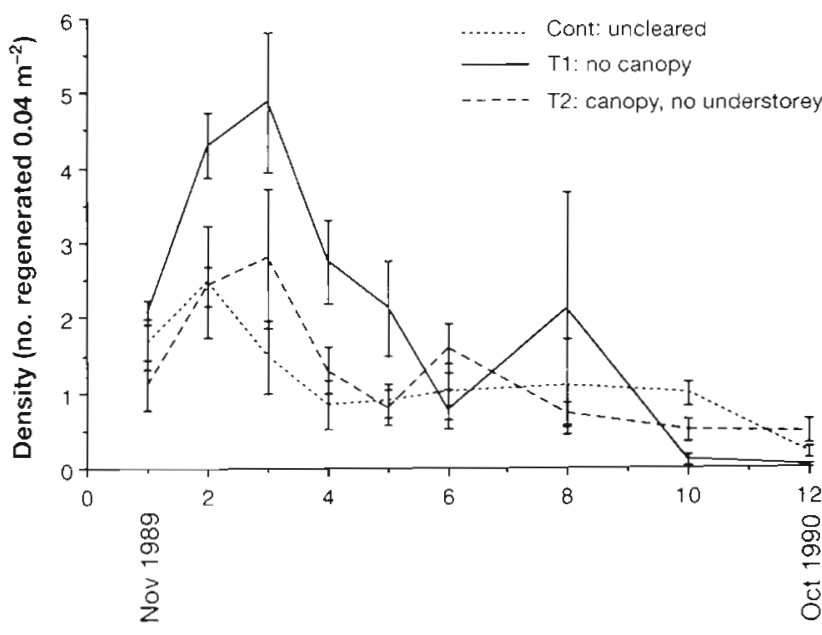

Fig. 7 Sargassum spp. Change in mean density of thalli regenerating from fragments of the holdfast ( $\pm S E, n=5$ ) with time after clearing (October 1989) for all treatments from the clearing experiment. Treatments - T1: no canopy (removal of all algae); T2: removal of understorey algae but canopy of Sargassum left intact; Cont: an unmanipulated control 
ing the spatial pattern of survival of propagules to visible recruits.

Vegetative regeneration is utilized by Sargassum to retain space on subtidal reefs. In the cleared treatment, large amounts of regeneration from fragments of holdfasts occurred (100 thalli $\mathrm{m}^{-2}$ ). Similarly, McCook \& Chapman (1992) found regeneration in Fucus, a related genus, to be important for its persistence in intertidal rocky shores. Vegetative regeneration occurred after severe clearing and scraping, suggesting that it would naturally occur at similar or higher rates (McCook \& Chapman 1992, this study). The variation in densities of regenerated thalli between individual $0.04 \mathrm{~m}^{-2}$ quadrats implies that adults are patchily distributed in the subtidal. This differs from studies of recruitment in kelps where clumped distributions of recruits resulted in random distributions of adult Macrocystis pyrifera (Dean et al. 1989). The difference is possibly because of the greater long-term influence that the canopy-forming kelps have on understorey (Dayton et al. 1984, Reed \& Foster 1984, Santelices \& Ojeda 1984). Sargassum canopy is seasonal at Rottnest Island (Kendrick 1992). The importance of vegetative regeneration versus recruitment from propagules cannot be determined from this 1 experiment, but recruitment can replace up to $1 / 3$ of the total adult population each year in some Sargassum beds at Rottnest Island (Kendrick 1992).

Patterns of dispersal and settlement can persist into the adult population. The densities of propagules settling within the Sargassum bed can be calculated from density of reproductive thalli (Kendrick 1992) and from known densities of dispersed propagules (Kendrick \& Walker 1991, Kendrick 1992). Between 35 and 40 adult thalli $\mathrm{m}^{-2}$ released propagules in November 1990 and 1991 (Kendrick 1992). If we assume these thalli are evenly distributed, a density of 36 adult thalli $\mathrm{m}^{-2}$ will result in thalli being separated by $16.6 \mathrm{~cm}$. The contributions of a reproductive thallus and its 8 nearest neighbours to the density of settled propagules can be calculated from previous studies of propagule disper-

Table 3. Densities of settled propagules of Sargassum spinuligerum (propagules $\mathrm{m}^{-2}$ ) recorded at $<10 \mathrm{~cm}$ distances from 80 reproductive thalli releasing propagules (Kendrick \& Walker 1991), and calculated for a single reproductive thallus and its 8 nearest neighbours ( 9 thalli)

\begin{tabular}{|ccccc|}
\hline $\begin{array}{c}\text { No. of } \\
\text { thalli }\end{array}$ & $\begin{array}{c}\text { Nov } 1990 \\
\text { mean } \\
(\mathrm{SE}, \mathrm{n}=4)\end{array}$ & $\begin{array}{c}\text { Dec } 1990 \\
\text { mean } \\
(\mathrm{SE}, \mathrm{n}=4)\end{array}$ & $\begin{array}{c}\text { Nov 1991 } \\
\text { mean } \\
(\mathrm{SE}, \mathrm{n}=4)\end{array}$ & $\begin{array}{c}\text { Dec } 1991 \\
\text { mean } \\
(\mathrm{SE}, \mathrm{n}=4)\end{array}$ \\
\hline 80 & $5.3 \times 10^{3}$ & $9.2 \times 10^{4}$ & $2.6 \times 10^{5}$ & $1.7 \times 10^{5}$ \\
9 & $\left(1.6 \times 10^{3}\right)$ & $\left(2.4 \times 10^{4}\right)$ & $\left(2.8 \times 10^{4}\right)$ & $\left(4.2 \times 10^{4}\right)$ \\
9 & $6.0 \times 10^{2}$ & $1.0 \times 10^{4}$ & $3.0 \times 10^{4}$ & $1.9 \times 10^{4}$ \\
\hline
\end{tabular}

sal (Kendrick \& Walker 1991, Kendrick 1992). The numbers of propagules settling with distance from 80 reproductive thalli were determined in November and December, 1991 and 1992. Densities of settled propagules decrease exponentially within $1 \mathrm{~m}$ of their parent thalli. The minimum density of settled propagules would occur at half the distance between thalli, or $8.3 \mathrm{~cm}$. From a single release of propagules, the minimum density of propagules settling between thalli within the Sargassum bed would range from $10^{2}$ (November 1990) to $10^{4}$ propagules $\mathrm{m}^{-2}$ (December 1990, November, December 1991) (Table 3). Sargassum is reproductive and releasing propagules for a period of 5 mo, between September and January, at Rottnest Island. The naturally occurring level of recruitment, as measured on unseeded plates, was $10^{3}$ recruits $\mathrm{m}^{-2}$. Yet, the density of recruits observed during the clearing experiment (1989-1990) was $\leq 10^{2}$ propagules $\mathrm{m}^{-2}$, suggesting that processes other than intraspecific competition are important in determining recruit survival. Patterns of recruitment discussed in this paper will affect the numbers of recruits surviving from settled propagules, but will not completely cancel the observed small-scale patchiness in propagule dispersal.

Whether the populations of Sargassum observed at Rottnest Island, Western Australia are regulated by the availability of propagules or by post-settlement survival has not been clarified in this study. I propose that an 'either/or' answer to the above statement is an over-simplification of the constantly changing dynamic between propagule availability and postsettlement survival. Persistence of patterns of dispersal and settlement happens when orders of magnitude differences in the numbers of settled propagules occur over distances of meters (Kendrick \& Walker 1991, Kendrick 1992). Recolonization of patches, extension of the Sargassum bed at its edges and colonization of new habitat are the most likely opportunities for persistence of dispersal patterns over the short term. Patterns of distribution of adults within beds of Sargassum will also reflect the history of settlement but with the observed high mortality of recruits, density-dependent growth, negative impact of adults and high rates of regeneration from fragments such a history may not be discernible.

Acknowledgements. This study represents research towards a Ph.D. degree at the Unversity of Western Australia and was partly funded by a UWA Janice Klumpp Award and an Australian postgraduate Research Award. I thank Nokome Bentley, Anne Brearley, Jo Buckee, Tim Carruthers, Amrit Work Kendrick, Dan Machin and Cameron Sim for their SCUBAdiving assistance in the field. This manuscript benefited greatly from the helpful comments of Di Walker, Peter Jernakoff, John Pearse and 2 anonymous reviewers. 


\section{LITERATURE CITED}

Amsler, C. D., Neushul, M. (1991). Photosynthetic physiology and chemical composition of spores of the kelps Macrocystis pyrifera, Nereocystıs luetkeana, Laminaria farlowil and Pterygophora californica (Phaeophyceae). J. Phycol. $27 \cdot 26 \quad 34$

Anderson, E. K., North, W. J. (1966). In situ studies of spore production and dispersal in the giant kelp, Macrocystis. In Gordon Young, E., McLachlan, J. L. (eds.) Proc. 5th int. Seaweed Symp. Pergamon Press, Toronto, p. 73-86

Ang, P. O. Jr (1985). Studies of the recruitment of Sargassum spp. (Sargassaceae, Phaeophyta) in Balibago, Calatagan, Philippines. J. exp. Mar. Biol. Ecol. 91. 293-301

Ang, P. O. Jr (1991). Natural dynamics of a Fucus distichus (Phaeophyceae, Fucales) population: reproduction and recruitment. Mar. Ecol. Prog. Ser. 78: 71-85

Black, W. R. (1974). Some biological interactions affecting intertidal populations of the kelp Egregia laevigata. Mar Biol. 28: $189-198$

Chapman, A. R. O. (1989). Abundance of Fucus spiralis and ephemeral seaweeds in a high eulittoral zone: effects of grazers, canopy and substratum type. Mar Biol. 102 $565-572$

Connell, J. H. (1985). The consequences of vanation in initial settlement versus post-settlement mortality in rocky intertidal communities. J. exp. mar. Biol. Ecol. 93: 11-45

Cousens, R. Hutchings, M. J. (1983). The relationship between density and mean frond weight in monospecific seaweed stands. Nature 301: 240-241

Davis, A. R. (1987). Variation in recruitment in the subtidal ascidian Podoclavella cylindrica (Quoy \& Gaimard): the role of substratum choice and early survival. J. exp. mar Biol. Ecol. 106: 57-71

Dayton, P. K., Currie, V., Gerrodette, T., Keller, B., Rosenthal R., Van Tresca, D. (1984). Patch dynamics and stability of some southern California kelp communities. Ecol. Monogr. 54: 253-289

Dean, T. A., Jacobsen, F. R., Thies, K., Lagos, S. L. (1988). Differential effects of grazing by white sea urchins on recruitment of brown algae. Mar. Ecol. Prog. Ser. 48: 99-102

Dean, T. A., Thies, K., Lagos, S. L. (1989). Survival of juvenile giant kelp: the effects of demographic factors, competitors, and grazers. Ecology 70: 483-495

de Eston, V. R., Bussab, W. O. (1990). An experimental analysis of ecological dominance in a rocky subtidal macroalgal community. J. exp. mar. Biol. Ecol. 136: 170-195

Devinney, J. S. Volse, L. A. (1978). Effects of sediments on the development of Macrocystis pyrifera gametophytes. Mar Biol. 48: 343-348

Deysher, L., Norton, T A. (1982). Dispersal and colonization in Sargassum muticum (Yendo) Fensholt. J. exp. mar. Biol Ecol. 56: 179-195

Deysher, L. E., Dean, T. A. (1986). In situ recruitment of sporophytes of the giant kelp, Macrocystıs pyrifera (L.) C. A. Agardh: effects of physical factors. J. exp. mar. Biol. Ecol. 103: $41-63$

Eisenhart, C., Solomon, H. (1947). Significance of the largest of a set of sample estimates of variance. In: Eisenhart, C., Halstay, M. W., Wallis, W. A. (eds.) Selected techniques of statistical analysis for scientific and industrial research and production and management engineering. Chap. 15. McGraw-Hill Book Co., New York, p. 385-394

Harper, J. L. (1977). Population biology of plants. Academic Press, London

Hoffman, A. J., Avila, M., Santelices, B. (1984). Interactions of nitrate and phosphate on the development of microscopic stages of Lessonia nigrescens Bory (Phaeophyta). J. exp. mar. Biol. Ecol. 78: 177-186

Hoffman, A. J., Ugarte, R. (1985). The arrival of propagules of marine macroalgae in the intertidal zone. J. exp. mar. Biol. Ecol. 92: 83-95

Holm, E. R. (1990). Effects of density-dependent mortality on the relationship between recruitment and larval settlement. Mar. Ecol. Prog. Ser. 60: 141-146

Hruby, T., Norton, T. A. (1979). Algal colonization on rocky shores in the Firth of Clyde. J. Ecol. 67: 65-77

Hughes, T P. (1990). Recruitment limitation, mortality, and population regulation in open systems: a case study. Ecology $71.12-20$

Kendrick, G. A. (1992). The role of dispersal and recruitment processes in structuring mixed species beds of Sargassum (Sargassaceae, Phaeophyta) at Rottnest Island, Western Australia. Ph.D. thesis, University of Western Australia, Nedlands

Kendrick, G. A. (1993). Sargassum beds at Rottnest Island species composition and abundance. In: Wells, F. E. Walker, D. 1., Kirkman, H., Lethbridge, R. (eds.) Proc. 5th int mar biol. Workshop: the flora and fauna of Rottnest Island, Western Australia. Western Australia Museum, Perth, p. 455-472

Kendrick, G. A., Walker, D. I. (1991). Dispersal distances for propagules of Sargassum spinuligerum (Sargassaceae Phaeophyta) directly measured by vital staining and venturi suction sampling. Mar. Ecol. Prog. Ser. 79: 133-138

Kennelly, S. J. (1989). Effects of kelp canopies on understorey species due to shade and scour. Mar Ecol. Prog. Ser. 50 $215-224$

Kennelly, S. J., Larkum, A. W. D. (1983). A preliminary study of temporal variation $1 n$ the colonization of subtidal algae in an Ecklonia radiata community. Aquat. Bot. 17: 275-282

Madansky, A. (1988). Prescriptions for working statisticians. Springer-Verlag, New York

McCook, L. J., Chapman, A. R. O. (1992). Vegetative regeneration of Fucus rockweed canopy as a mechanism of secondary succession on an exposed rocky shore. Botanica mar. 35: 35-46

McGuinness, K. A., Davis, A. R. (1989). Analysis and interpretation of the recruit-settler relationship. J. exp. Mar. Biol Ecol. 134: 197-202

Menge, B. A. (1991). Relative importance of recruitment and other causes of variation in rocky intertidal community structure. J. exp. mar. Biol. Ecol. 146: 69-100

Paula, E. J., Eston, V R. (1987). Are there other Sargassum species potentially as invasive as $S$. muticum. Botanica mar. 30: 405-410

Reed, D. C. (1987). Factors affecting the production of sporophylls in the giant kelp Macrocystis pyrifera (L.) C. Ag J. exp. mar Biol. Ecol. 113: 61-69

Reed, D. C. (1990). An experimental evaluation of density dependence in a subtidal algal population. Ecology 71 2286-2296

Reed, D. C., Foster, M. S. (1984). The effects of canopy shading on algal recruitment and growth in a giant kelp forest. Ecology 65: 937-948

Reed, D. C., Laur, D. R., Ebeling, A. W. (1988). Variation in algal dispersal and recruitment: the importance of episodic events. Ecol. Monogr. 58: 321-335

Reed, D. C., Neushul, M., Ebeling, A. W. (1991). Role of settlement density on gametophyte growth and reproduction in the kelps Pterygophora californica and Macrocystis pyrifera (Phaeophyceae). J. Phycol. 27: 361-366

Santelices, B., Ojeda, F. P. (1984). Effects of canopy removal on the understory algal community structure of coastal 
forests of Macrocystis pyrifera from southern South America. Mar. Ecol Prog. Ser. 14: 165-173

Schiel, D. R. (1985). Growth, survival and reproduction of two species of marine algae at different densities in natural stands. J. Ecol. 73: 199-217

Schiel, D. R., Choat, J. H. (1980). Effects of density on monospecific stands of marine algae. Nature 285: $324-326$

Schiel, D. R. Foster, M. S. (1986). The structure of subtidal algal stands in temperate waters. Oceanogr. mar. Biol. A. Rev. 24: 265-307

Sutherland. J. P. (1990). Recruitment regulates demographic

This article was submitted to the editor variation in a tropical intertidal barnacle. Ecology 71 955-972

Vadas, R. L., Wright, W. A., Miller, S. L. (1990). Recruitment of Ascophyllum nodosum: wave action as a source of mortality. Mar. Ecol. Prog. Ser. 61: 263-272

Velimirov, B., Griffiths, C. L. (1979). Wave-induced kelp movement and its importance for community structure. Botanica mar. 22: 169-172

Victor, B. C. (1986). Larval settlement and juvenile mortality in a recruitment-limited coral reef fish population. Ecol. Monogr. 156: 145-160

Manuscript first received: January 13,1993

Revised version accepted: October 5, 1993 